\title{
Outcomes of modified deep scleral trabeculectomy surgery under anterior chamber maintainer
}

\section{Ön kamara koruyucu altında modifiye derin skleral trabekülektomi cerrahisi sonuçlarımız}

Özcan Rasim Kayıkçiı̆glư ${ }^{1}$, Sinan Bilgin ${ }^{2}$

\begin{abstract}
Objective: To evaluate patients monitored for glaucoma and operated with trabeculectomy combined with deep sclerectomy under an anterior chamber maintainer.

Methods: In this retrospective study, fifteen eyes of 15 patients diagnosed with primary open angle glaucoma (POAG) who show up regularly for follow-up examinations between April 2006 and May 2010 were included in this study. Pre-operative/post-operative intraocular pressure (IOP) and the number of antiglaucomatous medications were evaluated.
\end{abstract}

Results: The mean age was $64.6 \pm 11.4$ (33-80) years and the mean follow-up period was $22.4 \pm 16.2$ months (6-55). The mean pre-operative IOP was $24.6 \pm 8.0$ (12$40 \mathrm{mmHg}$ ), and the mean cup/disc (c/d) ratio was $0.71 \pm$ 0.25 . According to the Hodapp classification, the mean damage in the visual field was $2.1 \pm 0.9$. Mean post-operative IOP at months 1,12 , and 24 was $13.2 \pm 3.4,13.6$ \pm 4.6 and $13.8 \pm 2.8 \mathrm{mmHg}$, respectively. The average number of pre-operative antiglaucomatous medications was 3.1 whereas the average numbers of post-operative antiglaucomatous medications were $1.8,0.6$ and 0.8 respectively.

Conclusion: Modified trabeculectomy has low rates of complication and results in a significant decrease in postoperative IOP, as well as the number of antiglaucomatous medications used. J Clin Exp Invest 2014; 5 (4): 544-547

Key words: Anterior chamber maintainer, deep sclerectomy, trabeculectomy

\section{INTRODUCTION}

Trabeculectomy was first described in 1967 and is a valid standard surgical technique in glaucoma treatment [1-2]. Although post-operative early period success rates are high, long-term effectiveness in controlling intraocular pressure (IOP) reduces [3-4].

\section{ÖZET}

Amaç: Glokom tanısı ile takip edilen ve ön kamara koruyucu altında derin skleral trabekülektomi operasyonu geçiren hastaların değerlendirilmesi.

Yöntemler: Bu çalışmaya Nisan 2006 - Mayıs 2010 tarihleri arasında primer açık açılı glokom (PAAG) tanısı almış, düzenli olarak kontrollere gelen 15 hastanın 15 gözü dahil edildi. Çalışmada preoperatif ve postoperatif göz içi basıncı (GiB), kullanılan ilaç etken madde sayıları değerlendirildi.

Bulgular: Yaş ortalaması $64,6 \pm 11,4$ (33-80) yıl, ortalama takip süresi $22,4 \pm 16,2$ ay (6-55) idi. Preoperatif ortalama GiB'ları 24,6 $\pm 8,0 \mathrm{mmHg}$ (12-40), ortalama cup/disk (c/d) oranı $0,71 \pm 0,25$ saptandı. Hastaların görme alanlarındaki hasar Hodapp sınıflamasına göre ortalama 2,1 $\pm 0,9$ idi. Postoperatif 1 . ay, 12. ay ve 24 . ay ortalama GiB'ları sırasıyla 13,2 $\pm 3,4,13,6 \pm 4,6$ ve 13,8 $\pm 2,8$ mmHg ölçüldü. Preoperatif kullanılan antiglokomatöz etken madde sayısı ortalama 3,1 iken, postoperatif ortalama sırasıyla 1,8, 0,6 ve 0,8 bulundu.

Sonuçlar: Çalışmamızda modifiye trabekülektomi cerrahisi düşük komplikasyon oranları ile hastaların postoperatif GiB'ında belirgin bir düşme sağlanmakta ve kullanılan ilaç sayısında belirgin bir azalmaya neden olmaktadır.

Anahtar kelimeler: Ön kamara koruyucu, derin sklerektomi, trabekülektomi

\footnotetext{
${ }^{1}$ Celal Bayar University, Faculty of Medicine, Department of Ophthalmology Manisa, Turkey

2 Şifa University Faculty of Medicine, Department of Ophthalmology, Izmir, Turkey
}

Correspondence: Sinan Bilgin,

Şifa University Faculty of Medicine, Department of Ophthalmology, İzmir, Turkey Email:drsinanbilgin@yahoo.com

Received: 12.09.2014, Accepted: 09.10.2014

Copyright @ JCEI / Journal of Clinical and Experimental Investigations 2014, All rights reserved 
post-operative period based on filtration rate. To this aim, various suture techniques were described [810]. Non-penetrating methods such as collagen implant deep scleretomy and viscocanalostomy were developed in order to reduce complication rates when maintaining effectivity of trabeculectomy [811]. Despite lower complication rates of these techniques, many studies reported lower IOP-lowering efficacy [12-15]. In this study, our aim was to report short and long term results of operations performed by modified scleral trabeculectomy technique under anterior chamber maintainer which enables scleral flap suture tension during operation.

\section{METHODS}

In this retrospective study, 15 eyes of 15 patients who had modified glaucoma surgery due to primary open-angle glaucoma between April 2006 and May 2010 were evaluated. All the study patients were operated by the same surgeon (Ö.K). Due to follow up problems, 9 patients were evaluated for the first year and 6 patients were evaluated for the second year.

Preoperative and postoperative IOP, the number of drug active substances were assessed. Fundamental eye examination was performed to all patients before surgery. Best-corrected visual acuity, IOP measurements by Goldmann applanation tonometer, glaucoma gonioscopy, fundus examination, biomicroscopic examination were done. All these examinations were repeated postoperative on day 1,7 , at month 1 and then by 3 month intervals until 24 month. Antimetabolite was not used in any of the operations.

Surgical technique: All operations were performed by the same surgeon under retrobulbar anesthesia. Periorbital skin area and eyelids were cleaned by $10 \%$ povidone-iodone before surgery. Eyelids and lashes were covered by a sterile eye covering. One drop of $5 \%$ povidone-iodone was instilled onto conjunctiva and washed by balanced saline solution (BSS). All operations were made from upper temporal or upper nasal quadrant and fornix-based conjunctival flap was made. Scleral vessels were cauterized following conjunctiva and Tenon dissections. Then, a $4 \times 4 \mathrm{~mm}$, limbus-based, square, superficial scleral flap was formed. The second deep scleral, $3 \times 3 \mathrm{~mm}$ flap was formed by tracing black reflection of choroid. The roof of Schlemm's canal was peeled during deep scleral flap excision from limbal region. Deep scleral flap was excised after reaching the Descemet membrane. At this stage, paracentesis was made from lower temporal quadrant by using a 20 gauge microvitreoretinal (MVR) knife to put the anterior chamber maintainer. Anterior chamber maintainer was closed. After removal of trabeculum tissue, peripheral iridectomy was made.

After putting the superficial scleral flap into its bed, it was sutured by a 10/0 monofilament (Alcon Surgical, Houston, TX, USA) material. Anterior chamber maintainer was opened and BSS drainage under scleral flap was observed. Bottle height was adjusted to $30 \mathrm{~cm}$ above the eye level in order to maintain IOP around $20 \mathrm{mmHg}$. Depending on the surgeon's choice, additional sutures were placed or suture tension was reduced according to the amount of filtration. The number of sutures varied between 2 to 5 . Conjunctiva was closed by $8 / 0$ vicryl. At the end of each operation, diffuse bleb development was observed by the action of anterior chamber maintainer in each patient.

In the statistical analysis, differences of means in paired groups were tested by Wilcoxon signed ranks. A p value $\leq 0.05$ was accepted as significant.

\section{RESULTS}

The mean age of patients was $64.6 \pm 11.4$ year (range, 33-80 year), and the mean follow up period was $22.4 \pm 16.2$ (6-55 month) month. In the preoperative period, the mean cup/disc (c/d) ratio was $0.71 \pm 0.25$ and the mean damage of visual field based on Hodapp classification was $2.1 \pm 0.9$. The mean preoperative IOP of patients under antiglaucomatous medication was $24.6 \pm 8.0 \mathrm{mmHg}(12-40$ $\mathrm{mmHg}$ ). Total 3 patients did not come to 6th month visit. Of these, one was taking medication starting from the end of the first month, whereas the remaining two were medication-free. Another 3 patients did not come to the $12^{\text {th }}$ month visit. Of these, one started 1 medication whereas the remaining two started 2 medications at the 9 month. Nine patients completed 12 month visits. Among the final 9, six patients completed 24 month visits whereas 3 patients failed to attend the visits.

The mean postoperative IOP values at months 1,12 and 24 was $13.2 \pm 3.4 \mathrm{mmHg}, 13.6 \pm 4.6 \mathrm{mmHg}$, and $13.8 \pm 2.8 \mathrm{mmHg}$, respectively. The mean number of preoperative antiglaucomatous active substance was 3.1 whereas postoperative values were 1.8, 0.6 and 0.8 respectively (Table 1 ). There were significant reductions in postoperative IOP values and number of active substance $(p<0.05)$. 
During control visits of the patients, choroid detachment in one patient, and 10-0 suture irritation in another patient were observed. None of the patients revealed any sign of severe inflammation in anterior chamber.

Table 1. Preoperative and postoperative mean intraocular pressure (IOP) values and number of used active substances

\begin{tabular}{lcc}
\hline & IOP $(\mathrm{mmHg})$ & $\begin{array}{c}\text { Number of } \\
\text { Drug Active } \\
\text { Substance }\end{array}$ \\
\hline Preoperative & $\begin{array}{c}24.6 \pm 8.03 \\
(\mathrm{n}=15)\end{array}$ & 3.1 \\
Postoperative 1 ${ }^{\text {st }}$ month & $\begin{array}{c}13.2 \pm 3.4 \\
(\mathrm{n}=15)\end{array}$ & 1.8 \\
Postoperative 12th month & $\begin{array}{c}14 \pm 4.3 \\
(\mathrm{n}=9)\end{array}$ & 0.6 \\
Postoperative 24 & $\begin{array}{c}\text { th } \text { month } \\
13.8 \pm 2.8 \\
(\mathrm{n}=6)\end{array}$ & 0.8 \\
\hline
\end{tabular}

\section{DISCUSSION}

Many modifications were described to reduce complication rate and enhance filtration rate since the first introduction of trabeculectomy. However, fundamentals of trabeculectomy were not changed during the years and it is still the gold-standard of glaucoma surgery. Non-penetrating glaucoma surgery, which was described by Krasnov in 1968, is the most popular alternative surgical method to trabeculectomy [16]. When compared to trabeculectomy, the most important advantage of non-penetrating surgery is lower complication rate [1, 5-8].

On the other hand, the most important complications include trabeculodescemetic membrane rupture which may develop at high rates during deep sclerectomy and ineffective surgery.

Filtration failure problem of deep sclerectomy is solved by trabecular membrane rupture made by yttrium aluminium garnet (YAG) laser. Thus, nonpenetrating surgery turns into penetrating surgery. After deep sclerotomy, 30 to $81 \%$ of the patients require YAG goniopuncture [17-20].

Shiota et al reported high incomplete success rates of $94 \%$ to $88 \%$ at the end of 5 th and 10 th years after trabeculectomy surgery in POAG patients [21]. Cillino et al found complete and incomplete success rates $55 \%$ and $88.9 \%$, respectively, in open-angle glaucoma patients with a 12-month follow up period [22].
Combined trabeculectomy and deep sclerectomy were first described by Feusier et al [23]. The study included juvenile, congenital and secondary glaucoma patients. Complete $(\mathrm{IOP}<21 \mathrm{mmHg}$, with out medication) and incomplete (IOP $<21 \mathrm{mmHg}$, with medication) full success rates in this heterogeneous group after nine years were $52.3 \%$ and $70.6 \%$.

In our study group, complete and incomplete success rates of nine patients who completed 12 month follow up visits, were $77.7 \%$ and $100 \%$, respectively, whereas these figure were $66.6 \%$ and $100 \%$ at month 24 . The major weakness of our study is ineffective follow up visits which led to loss of 6 patients. It may be considered that patients with problems remained to attend follow up visits or some patients lost their belief for healing. The reason for success rate alterations at month 24 was drop of 3 patients who were not on medication.

Determining the filtration resistance by adjusting suture tension and number under a anterior chamber maintainer might increase our surgical success rates. The aim of this technique is to create a potential space by deep sclerectomy and to obtain perioperative control of filtration rate and suture tension by anterior chamber maintainer. In addition, use of maintainer increases surgical success via removing inflammatory mediators and hemorrhage at the last stage of surgery. In order to prevent corneal endothelial cell damage due to turbulence, anterior chamber protector was used at the last stage of surgery and none of the patients developed postoperative corneal edema.

Bayaoumi reported $20 \%$ disc edema due to hypotonia with surgery in which deep sclerectomy, mitomycin C + trabeculectomy were combined in pediatric glaucoma patients [24]. Munteanum et al. reported decompression retinopathy as a complication in a patient who underwent deep sclerectomy combined with trabeculectomy [25]. In our study, no complication was observed in any of the patients during surgery, but during postoperative period, one patient had choroid detachment and another patient had suture irritation.

In conclusion, adjusting scleral flap suture tension during surgery under the anterior chamber maintainer is a new and rarely used concept. This may be an alternative for adjusting postoperative filtration rate. One limitation of this study was weak follow up monitorization. Therefore, only available data were evaluated and presented. For a detailed comparison, prospective randomized studies with 
larger patient groups and equal follow up periods should be performed.

\section{REFERENCES}

1. Mermoud A, Schnyder CC. Nonpenetrating filtering surgery in glaucoma. Curr Opin Ophthalmol 200;11:151157.

2. Ambresin A, Shaarawy T, Mermoud A. Deep sclerectomy with collagen implant in one eye compared with trabeculectomy in the other eye of the same patient. J Glaucoma 2002;11:214-220.

3. Molteno AC, Bosma NJ, Kittelson JM. Otago glaucoma surgery outcome study: long-term results of trabeculectomy-1976 to 1995. Ophthalmology 1999;106:1742-1750.

4. Chen TC, Wilensky JT, Viana MA. Long-term follow-up of initially successful trabeculectomy. Ophthalmology 1997;104:1120-1125.

5. Crandall AS. Nonpenetrating filtering procedures: viscocanalostomy and collagen wick. Semin Ophthalmol 1999;14:189-195.

6. Sarodia U, Shaarawy T, Barton K. Nonpenetrating glaucoma surgery: a critical evaluation. Curr Opin Ophthalmol. 2007;18:152-158.

7. Lachkar Y, Neverauskiene J, Jeanteur-Lunel MN, et al. Nonpenetrating deep sclerectomy: a 6-year retrospective study. Eur J Ophthalmol 2004;14:26-36.

8. Jones E, Clarke J, Khaw PT. Recent advances in trabeculectomy technique. Curr Opin Ophthalmol 2005;16:107-113.

9. Wells AP, Bunce C, Khaw PT. Flap and suture manipulation after trabeculectomy with adjustable sutures: titration of flow and intraocular pressure in guarded filtration surgery. J Glaucoma 2004;13:400-406.

10. Wanner JB, Katz LJ. Releasable suture techniques for trabeculectomy: an illustrative review. Ophthalmic Surg Lasers Imaging 2004;35:465-474.

11. El Sayyad F, Helal M, El-Kholify H, et al. Nonpenetrating deep sclerectomy versus trabeculectomy in bilateral primary open-angle glaucoma. Ophthalmology 2000;107:1671-1674.

12. Yalvac IS, Sahin M, Eksioglu U, et al. Primary viscocanalostomy versus trabeculectomy for primary open angle glaucoma: three-year prospective randomized clinical trial. J Cataract Refract Surg 2004;30:20502057.
13. Stegmann RC, Pienaar A, Miller D. Viscocanalostomy for open-angle glaucoma in black African patients. J Cataract Refract Surg 1999;25:316-321.

14. Karlen M, Sanchez E, Schnyder CC et al. Deep sclerectomy with collagen implant: medium term results. Br J Ophthalmol 1999;83:6-11.

15. Demailly $P$, Lavat $P$, Kretz G, et al. Non penetrating deep sclerectomy (NPDS) with or without collagen devices in primary open angle glaucoma: middle term retrospective study. Int Ophthalmol 1999:20:131-134.

16. Krasnov MM. Externalization of Schlemm's canal (sinusotomy) in glaucoma. Br J Ophthal 1968;52:157161.

17. Mermoud A, Karlen ME, Schnyder C, et al. Nd:Yag goniopuncture after deep sclerectomy with collagen implant. Ophthalmic Surg Lasers 1999;30:120-125.

18. Devloo S, Deghislage C, Van Malderen L, et al. Nonpenetrating deep sclerectomy without or with autologous scleral implant in open -angle glaucoma: mediumterm results. Graefes Arch Clin Exp Ophthalmol 2005;243:1206-1212.

19. Mousa AS. Preliminary evaluation of nonpenetrating deep sclerectomy with autologous scleral implant in open-angle glaucoma. Eye 2007;21:1234-1238.

20. Shaarawy T, Mansouri K, Schnyder $C$ et al. Longterm results of deep sclerectomy with collagen implant. J Cataract Refract Surg 2007;30:1225-1231.

21. Sihota R, Gupta V, Agarwal HC. Long-term evaluation of trabeculectomy in primary open angle glaucoma and chronic primary angle closure glaucoma in an Asian population. Clin Experiment Ophthalmol 2004;32:23-28.

22. Cillino S, Di Pace F, Casuccio A, et al. Deep sclerectomy versus punch trabeculectomy with or without phacoemulsification: a randomized clinical trial. J Glaucoma 2004;13:500-506.

23. Feusier M, Roy S, Mermoud A. Deep sclerectomy combined with trabeculectomy in pediatric glaucoma. Ophthalmology 2009;116:30-38.

24. Bayoumi NH. Deep sclerectomy in pediatric glaucoma filtering surgery. Eye (Lond) 2012;26:1548-1553.

25. Munteanu M, Munteanu G, Zolog I, et al. Ocular decompression retinopathy after combined deep sclerectomy and trabeculotomy. Klin Monbl Augenheilkd 2012;229:830-831. 